\title{
Fabrication of nanoadjuvant with poly- $\varepsilon$-caprolactone (PCL) for developing a single-shot vaccine providing prolonged immunity [Corrigendum]
}

Prashant CK, Bhat M, Srivastava SK, et al. Int J Nanomedicine. 2014;9:937-950.

On page 937, the author affiliations have been listed incorrectly. The correct author list is as follows:

Chandravilas Keshvan Prashant ${ }^{1}$

Madhusudan Bhat ${ }^{2}$

Sandeep Kumar Srivastava ${ }^{2}$

Ankit Saxena ${ }^{3}$

Manoj Kumar ${ }^{4}$

Amar Singh ${ }^{3}$

Mohammed Samim 5

Farhan Jalees Ahmad ${ }^{6}$

Amit Kumar Dinda ${ }^{2}$
${ }^{1}$ Faculty of Engineering and Interdisciplinary Sciences, Jamia Hamdard, New Delhi, India; ${ }^{2}$ Department of Pathology, ${ }^{3}$ Department of Transplant Immunology and Immunogenetics, All India Institute of Medical Sciences, New Delhi, India; ${ }^{4}$ Centre for Biomedical Engineering, Indian Institute of Technology, New Delhi, India; ${ }^{5}$ Department of Chemistry, Faculty of Science, Jamia Hamdard, New Delhi, India; ${ }^{6}$ Department of Pharmaceutics, Faculty of Pharmacy, Jamia Hamdard, New Delhi, India
International Journal of Nanomedicine

\section{Publish your work in this journal}

The International Journal of Nanomedicine is an international, peerreviewed journal focusing on the application of nanotechnology in diagnostics, therapeutics, and drug delivery systems throughou the biomedical field. This journal is indexed on PubMed Central, MedLine, CAS, SciSearch ${ }^{\circledR}$, Current Contents ${ }^{\circledR} /$ Clinical Medicine,

\section{Dovepress}

Journal Citation Reports/Science Edition, EMBase, Scopus and the Elsevier Bibliographic databases. The manuscript management system is completely online and includes a very quick and fair peer-review system, which is all easy to use. Visit http://www.dovepress.com/ testimonials.php to read real quotes from published authors. 